\title{
Once Weekly
}

National Cancer Institute

\section{Source}

National Cancer Institute. Once Weekly. NCI Thesaurus. Code C64526.

One time per week. 